\title{
Editorial
}

\section{Eberhard F. Mammen Award Announcements: Part I - Most Popular Articles}

\author{
Emmanuel J. Favaloro, PhD, FFSc (RCPA) ${ }^{1}$ \\ ${ }^{1}$ Department of Haematology, Institute of Clinical Pathology and \\ Medical Research (ICPMR), Westmead Hospital, Westmead, \\ NSW, Australia
}

Semin Thromb Hemost 2016;42:325-330.

Welcome to the latest of our Eberhard F. Mammen award announcements. As noted previously, ${ }^{1-3}$ Thieme, the publisher of Seminars in Thrombosis \& Hemostasis, has created the Eberhard F. Mammen Excellence in Thrombosis and Hemostasis Awards in honor of Eberhard Mammen (-Fig. 1) and in recognition of his contribution to this field and to the journal that he both founded and steered for over three decades. These awards began in 2009, under two categories, "Most Popular Article Awards" and "Young Investigator Awards." Current details and conditions of the award can be summarized as:

- Most Popular Article Awards: The awards are given to the authors of the most popular articles published in Seminars in Thrombosis $\mathcal{E}$ Hemostasis. The awards are determined by the Editor in Chief on the basis of user statistics from Thieme e-Journals from the preceding 2 years. Prefaces, Errata, Letters

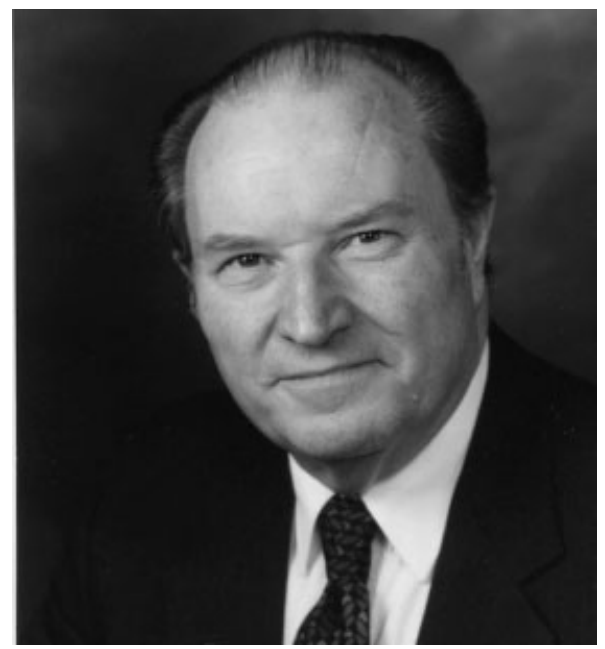

Fig. 1 Eberhard F. Mammen (1930-2008).

Address for correspondence Emmanuel J. Favaloro, PhD, FFSc (RCPA), Department of

Haematology, Institute of Clinical Pathology and Medical Research (ICPMR), Westmead Hospital, Westmead, NSW, 2145, Australia (e-mail: emmanuel.

favaloro@health.nsw.gov.au).

to the Editor, Editorials, and previous award-winning articles are excluded from further consideration of these awards, which currently comprise two categories-one for "Open Access" articles, and another for a "General Category." There are two major cash prizes of US\$1,000 for each category. In addition, winners of the "General Category" awards are granted "open-access" status for these articles thereafter.

- Young Investigator Awards: These award are given for best presentation or meeting abstract by a young investigatoras presented or delivered to an international or large regional meeting on a topic related to the fields of thrombosis and hemostasis, and whose subject matter is determined to be in the spirit of Dr. Mammen. There are up to six cash prizes of US\$1,000 in any year. There are some additional considerations and conditions for the award, and awardees are expected to prepare a review or other paper related to the topic of their presentation for publication in Seminars in Thrombosis \& Hemostasis.

Further details of the awards and the award winners are posted online http://www.thieme.com/sth), and previous award winner announcements are also available in print. ${ }^{4-13}$

It is therefore with great pleasure that we would like to announce the latest winners of the 2016 Eberhard F. Mammen awards for the most popular articles from Seminars in Thrombosis $\mathcal{E}$ Hemostasis for the period of 2014-2015 inclusive. We will be announcing the Young Investigator Awards related to meetings held in the recent past at a forthcoming opportunity.

\section{6 “Most Popular Article” Awards}

As mentioned, the Most Popular awards are given to the authors of the most popular articles published in Seminars in Thrombosis $\mathcal{E}$ Hemostasis as determined on the basis of user statistics from

Copyright (c) 2016 by Thieme Medical Publishers, Inc., 333 Seventh Avenue, New York, NY 10001, USA. Tel: +1(212) 584-4662.
DOI http://dx.doi.org/ 10.1055/s-0036-1581108. ISSN 0094-6176.
Hemostasis, and the Identification and Treatment of Associated Disorders; Guest Editors: Ton Lisman, PhD, and Philippe de Moerloose, MD. 
the publisher of this journal and covering the preceding 2-year period. Thus, the 2016 "Most Popular" awards are granted to the most popular papers from 2014-2015 inclusive. Previous Eberhard F. Mammen award-winning articles are listed in - Table 1. These articles are currently available under an "Open Access" status, and no longer qualify for future awards, although many will continue to appear in the most popular download statistics provided by the publisher.

There is also an increasingly recognized trend to publish articles in an open-access mode, and these have an "inequitable advantage" over other "non-open-access" articles in terms of downloads due to their open accessibility. Accordingly, the publisher of Seminars in Thrombosis $\mathcal{E}$ Hemostasis has established a separate category of the Most Popular Award for "open-access" papers, to supplement the alternate "General Category," and thus the most popular papers are now listed in separate tables. - Table 2 lists the top 15 downloaded open-access articles from Seminars in Thrombosis \& Hemostasis (2014 and 2015 inclusive) eligible for the "Open Access" award. ${ }^{14-28}$ - Table 3 lists the top 15 downloaded non-open-access articles from Seminars in Thrombosis \& Hemostasis (2014 and 2015 inclusive) eligible for the "General Category" award. ${ }^{29-43}$

Accordingly, the 2016 Eberhard F. Mammen award winners for Most Popular Articles (2014-2015 inclusive) are as follows:

\section{Open Access Category}

1. Bates SM. D-dimer assays in diagnosis and management of thrombotic and bleeding disorders. Semin Thromb Hemost 2012;38(7):673-682

2. Lippi G, Favaloro EJ, Meschi T, Mattiuzzi C, Borghi L, Cervellin G. E-cigarettes and cardiovascular risk: beyond science and mysticism. Semin Thromb Hemost 2014;40 (1):60-65

\section{General Category}

1. de Moerloose P, Casini A, Neerman-Arbez M. Congenital fibrinogen disorders: an update. Semin Thromb Hemost 2013;39(6):585-595

Table 1 Previous most popular award winning papers

\begin{tabular}{|c|c|}
\hline Year & Awarded for \\
\hline 2009 & Jurk K, Kehrel BE. Platelets: physiology and biochemistry. Semin Thromb Hemost 2005;31(4):381-392 \\
\hline 2009 & Girolami B, Girolami A. Heparin-induced thrombocytopenia: a review. Semin Thromb Hemost 2006;32(8):803-809 \\
\hline 2010 & $\begin{array}{l}\text { Harenberg J, Wehling M. Current and future prospects for anticoagulant therapy: inhibitors of factor Xa and factor Ila. } \\
\text { Semin Thromb Hemost 2008;34(1):39-57 }\end{array}$ \\
\hline 2010 & $\begin{array}{l}\text { Prechel M, Walenga JM. The laboratory diagnosis and clinical management of patients with heparin-induced } \\
\text { thrombocytopenia: an update. Semin Thromb Hemost 2008;34(1):86-96 }\end{array}$ \\
\hline 2010 & $\begin{array}{l}\text { Fareed J, Hoppensteadt DA, Fareed D, et al. Survival of heparins, oral anticoagulants, and aspirin after the year } 2010 . \\
\text { Semin Thromb Hemost 2008;34(1):58-73 }\end{array}$ \\
\hline 2011 & $\begin{array}{l}\text { Sobieraj-Teague M, O’Donnell M, Eikelboom J. New anticoagulants for atrial fibrillation. Semin Thromb Hemost } 2009 ; 35 \\
\text { (5):515-524 }\end{array}$ \\
\hline 2011 & Mariani G, Bernardi F. Factor VII deficiency. Semin Thromb Hemost 2009;35(4):400-406 \\
\hline 2012 & $\begin{array}{l}\text { Lippi G, Franchini M, Favaloro EJ, Targher G. Moderate red wine consumption and cardiovascular disease risk: beyond the } \\
\text { "French paradox." Semin Thromb Hemost 2010;36(1):59-70 }\end{array}$ \\
\hline 2012 & Rak J. Microparticles in cancer. Semin Thromb Hemost 2010;36(8):888-906 \\
\hline 2013 & $\begin{array}{l}\text { Fava C, Montagnana M, Favaloro EJ, Guidi GC, Lippi G. Obstructive sleep apnea syndrome and cardiovascular diseases. } \\
\text { Semin Thromb Hemost 2011;37(3):280-297 }\end{array}$ \\
\hline 2013 & $\begin{array}{l}\text { Tufano A, Guida A, Dario Di Minno MN, Prisco D, Cerbone AM, Minno GD. Prevention of venous thromboembolism in } \\
\text { medical patients with thrombocytopenia or with platelet dysfunction: a review of the literature. Semin Thromb Hemost } \\
2011 \text { Apr;37(3):267-274 }\end{array}$ \\
\hline 2014 & $\begin{array}{l}\text { Salmela B, Joutsi-Korhonen L, Armstrong E, Lassila R. Active online assessment of patients using new oral anticoagulants: } \\
\text { bleeding risk, compliance, and coagulation analysis. Semin Thromb Hemost 2012;38(1):23-30 }\end{array}$ \\
\hline 2014 & $\begin{array}{l}\text { Chapman K, Seldon M, Richards R. Thrombotic microangiopathies, thrombotic thrombocytopenic purpura, and } \\
\text { ADAMTS-13. Semin Thromb Hemost 2012;38(1):47-54 }\end{array}$ \\
\hline 2014 & $\begin{array}{l}\text { Kenet G, Aronis S, Berkun Y, et al. Impact of persistent antiphospholipid antibodies on risk of incident symptomatic } \\
\text { thromboembolism in children: a systematic review and meta-analysis. Semin Thromb Hemost 2011;37(7):802-809 }\end{array}$ \\
\hline 2015 & Tapson VF. Thrombolytic therapy for acute pulmonary embolism. Semin Thromb Hemost 2013;39(4):452-458 \\
\hline 2015 & $\begin{array}{l}\text { George JN, Charania RS. Evaluation of patients with microangiopathic hemolytic anemia and thrombocytopenia. Semin } \\
\text { Thromb Hemost 2013;39(2):153-160 }\end{array}$ \\
\hline $2015^{\mathrm{a}}$ & Hylek EM. Anticoagulation therapy for atrial fibrillation. Semin Thromb Hemost 2013;39(2):147-152 \\
\hline $2015^{\mathrm{a}}$ & Rojas-Hernandez CM, Garcia DA. The novel oral anticoagulants. Semin Thromb Hemost 2013;39(2):117-126 \\
\hline
\end{tabular}

${ }^{\mathrm{a} N e w}$ open-access category. 
2. Sethi S, Fervenza FC. Pathology of renal diseases associated with dysfunction of the alternative pathway of complement: C3 glomerulopathy and atypical hemolytic uremic syndrome (aHUS). Semin Thromb Hemost 2014;40 (4):416-421

Although I was a co-author of one of the "Most Popular" award-winning papers, my contribution to this piece was limited. Moreover, I will excuse myself from any personal receipt of any aspect of the award. Accordingly, I do not consider there to be any conflict of interest in the publisher of Seminars in Thrombosis $\mathcal{E}$ Hemostasis awarding the award to the lead author, Prof. Giuseppe Lippi.

All authors of the award-winning articles were thrilled to hear that their papers had won an Eberhard F. Mammen Most Popular award, and provided the following additional responses:

From Dr. Shannon Bates (-Fig. 2), "I was surprised and very pleased to hear that my article had been awarded one of 2016 Most Popular Article Awards. Although I enjoy the opportunity that writing a review article provides to thoughtfully examine and synthesize the available literature, I must admit that I often wonder whether the resulting manuscript is of benefit to readers or even noticed. I am delighted, therefore, to find out that readers have found my article useful. It is an honor to receive this award."
From Dr. Giuseppe Lippi ( - Fig. 3), "I was really delighted to know that our article on 'e-cigarettes and cardiovascular risk' had won one of the Eberhard Mammen Seminars in Thrombosis \& Hemostasis 2015 most popular article awards. The issues of the possible health hazard posed by E-cigarettes is as relevant now as ever, if one considers that approximately two thirds of national governments around the globe have established strict regulations for e-cigarettes as of 2015. Briefly, in 2014 the European Union established new regulations forbidding advertising, setting limits on maximum concentrations of nicotine, limiting volumes of liquid that can be sold, requiring child-proof and tamper-proof packaging and empowering regulators to take act should the regulations be violated. In April 2014 in Australia, a court decision has made it illegal to sell or supply electronic cigarettes in Western Australia, regardless of their appearance or nicotine content. In the US, with a lack of federal regulations, many states use local e-cigarette regulations, most commonly to prohibit sales to minors. It is also noteworthy that the US Food and Drug Administration (FDA) agency has recently established an on-line database (i.e., Adverse Event Reports for e-Cigarettes), aiming to collect voluntary reports of adverse events involving e-cigarettes from consumers, health professionals and members of the public. Health concerns were mostly related to the evidence of enhanced risk of cardiac

Table 2 Most popular papers-“Open Access” category

\begin{tabular}{|c|c|}
\hline Rank & Publication \\
\hline 1 & $\begin{array}{l}\text { Bates SM. D-dimer assays in diagnosis and management of thrombotic and bleeding disorders. Semin Thromb Hemost } \\
\text { 2012;38(7):673-682 }\end{array}$ \\
\hline 2 & $\begin{array}{l}\text { Lippi G, Favaloro EJ, Meschi T, Mattiuzzi C, Borghi L, Cervellin G. E-cigarettes and cardiovascular risk: beyond science and } \\
\text { mysticism. Semin Thromb Hemost 2014;40(1):60-65 }\end{array}$ \\
\hline 3 & $\begin{array}{l}\text { Moore GW. Recent guidelines and recommendations for laboratory detection of lupus anticoagulants. Semin Thromb } \\
\text { Hemost } 2014 ; 40(2): 163-171\end{array}$ \\
\hline 4 & $\begin{array}{l}\text { Cuker A. Clinical and laboratory diagnosis of heparin-induced thrombocytopenia: an integrated approach. Semin } \\
\text { Thromb Hemost 2014;40(1):106-114 }\end{array}$ \\
\hline 5 & $\begin{array}{l}\text { Demers M, Wagner DD. NETosis: a new factor in tumor progression and cancer-associated thrombosis. Semin Thromb } \\
\text { Hemost 2014;40(3):277-283 }\end{array}$ \\
\hline 6 & $\begin{array}{l}\text { Raskob GE, Angchaisuksiri P, Blanco AN, et al.; ISTH Steering Committee for World Thrombosis Day. Thrombosis: a major } \\
\text { contributor to global disease burden. Semin Thromb Hemost 2014;40(7):724-735 }\end{array}$ \\
\hline 7 & Favaloro EJ. Clinical utility of the PFA-100. Semin Thromb Hemost 2008;34(8):709-733 \\
\hline 8 & Warkentin TE. Heparin-induced thrombocytopenia in critically ill patients. Semin Thromb Hemost 2015;41(1):49-60 \\
\hline 9 & $\begin{array}{l}\text { Zolfaghari S, Harenberg J, Froelich L, Wehling M, Weiss C. Development of a tool to identify patients' preference for } \\
\text { vitamin } \mathrm{k} \text { antagonist or direct oral anticoagulant therapy. Semin Thromb Hemost } 2014 ; 40(1): 121-128\end{array}$ \\
\hline 10 & Althaus K, Greinacher A. MYH9-related platelet disorders. Semin Thromb Hemost 2009;35(2):189-203 \\
\hline 11 & Nurden AT. Platelet membrane glycoproteins: a historical review. Semin Thromb Hemost 2014;40(5):577-584 \\
\hline 12 & $\begin{array}{l}\text { Harenberg J, Kraemer S, Du S, et al. Determination of direct oral anticoagulants from human serum samples. Semin } \\
\text { Thromb Hemost 2014;40(1):129-134 }\end{array}$ \\
\hline 13 & $\begin{array}{l}\text { Favaloro EJ, Lippi G. Laboratory testing in the era of direct or non-vitamin k antagonist oral anticoagulants: a practical } \\
\text { guide to measuring their activity and avoiding diagnostic errors. Semin Thromb Hemost 2015;41(2):208-227 }\end{array}$ \\
\hline 14 & $\begin{array}{l}\text { Wada H, Usui M, Sakuragawa N. Hemostatic abnormalities and liver diseases. } \\
\text { Semin Thromb Hemost 2008;34(8):772-778 }\end{array}$ \\
\hline 15 & $\begin{array}{l}\text { Harenberg J, Du S, Krämer S, Weiss C, Krämer R, Wehling M. Patients' serum and urine as easily accessible samples for the } \\
\text { measurement of non-vitamin k antagonist oral anticoagulants. Semin Thromb Hemost 2015;41(2):228-236 }\end{array}$ \\
\hline
\end{tabular}


Table 3 Most popular papers-“General Category”

\begin{tabular}{|c|c|}
\hline Rank & Publication \\
\hline 1 & $\begin{array}{l}\text { de Moerloose P, Casini A, Neerman-Arbez M. Congenital fibrinogen disorders: an update. Semin Thromb Hemost } \\
\text { 2013;39(6):585-595 }\end{array}$ \\
\hline 2 & $\begin{array}{l}\text { Sethi S, Fervenza FC. Pathology of renal diseases associated with dysfunction of the alternative pathway of complement: } \\
\text { C3 glomerulopathy and atypical hemolytic uremic syndrome (aHUS). Semin Thromb Hemost 2014;40(4):416-421 }\end{array}$ \\
\hline 3 & $\begin{array}{l}\text { Riedl M, Fakhouri F, Le Quintrec M, et al. Spectrum of complement-mediated thrombotic microangiopathies: } \\
\text { pathogenetic insights identifying novel treatment approaches. Semin Thromb Hemost 2014;40(4):444-464 }\end{array}$ \\
\hline 4 & Duga S, Salomon O. Congenital factor XI deficiency: an update. Semin Thromb Hemost 2013;39(6):621-631 \\
\hline 5 & $\begin{array}{l}\text { Vivarelli M, Emma F. Treatment of C3 glomerulopathy with complement blockers. Semin Thromb Hemost 2014;40 } \\
\text { (4):472-477 }\end{array}$ \\
\hline 6 & Baskurt OK, Meiselman HJ. Blood rheology and hemodynamics. Semin Thromb Hemost 2003;29(5):435-450 \\
\hline 7 & $\begin{array}{l}\text { Senoo K, Lip GY. Comparative efficacy and safety of the non-vitamin k antagonist oral anticoagulants for patients with } \\
\text { nonvalvular atrial fibrillation. Semin Thromb Hemost } 2015 ; 41(2): 146-153\end{array}$ \\
\hline 8 & $\begin{array}{l}\text { Rodríguez de Córdoba S, Hidalgo MS, Pinto S, Tortajada A. Genetics of atypical hemolytic uremic syndrome (aHUS). } \\
\text { Semin Thromb Hemost 2014;40(4):422-430 }\end{array}$ \\
\hline 9 & $\begin{array}{l}\text { Boonyawat K, Crowther MA. Venous thromboembolism prophylaxis in critically ill patients. Semin Thromb Hemost } \\
\text { 2015;41(1):68-74 }\end{array}$ \\
\hline 10 & $\begin{array}{l}\text { Xiao X, Pickering MC, Smith RJ. C3 glomerulopathy: the genetic and clinical findings in dense deposit disease and C3 } \\
\text { glomerulonephritis. Semin Thromb Hemost. 2014;40(4):465-471 }\end{array}$ \\
\hline 11 & Levi M, Poll TV. Coagulation in patients with severe sepsis. Semin Thromb Hemost 2015;41(1):9-15 \\
\hline 12 & $\begin{array}{l}\text { Franchini M, Coppola A, Tagliaferri A, Lippi G. FEIBA versus NovoSeven in hemophilia patients with inhibitors. Semin } \\
\text { Thromb Hemost 2013;39(7):772-778 }\end{array}$ \\
\hline 13 & $\begin{array}{l}\text { Lippi G, Favaloro EJ, Mattiuzzi C. Combined administration of antibiotics and direct oral anticoagulants: a renewed } \\
\text { indication for laboratory monitoring? Semin Thromb Hemost 2014;40(7):756-765 }\end{array}$ \\
\hline 14 & $\begin{array}{l}\text { Knöbl P. Inherited and acquired thrombotic thrombocytopenic purpura (TTP) in adults. } \\
\text { Semin Thromb Hemost 2014;40(4):493-502 }\end{array}$ \\
\hline 15 & Levi M, Schultz M, van der Poll T. Sepsis and thrombosis. Semin Thromb Hemost 2013;39(5):559-566 \\
\hline
\end{tabular}

arrhythmias, hypertension and cardiovascular events, which may be further magnified by other potential effects such as increased respiratory and flow respiratory resistance. We are

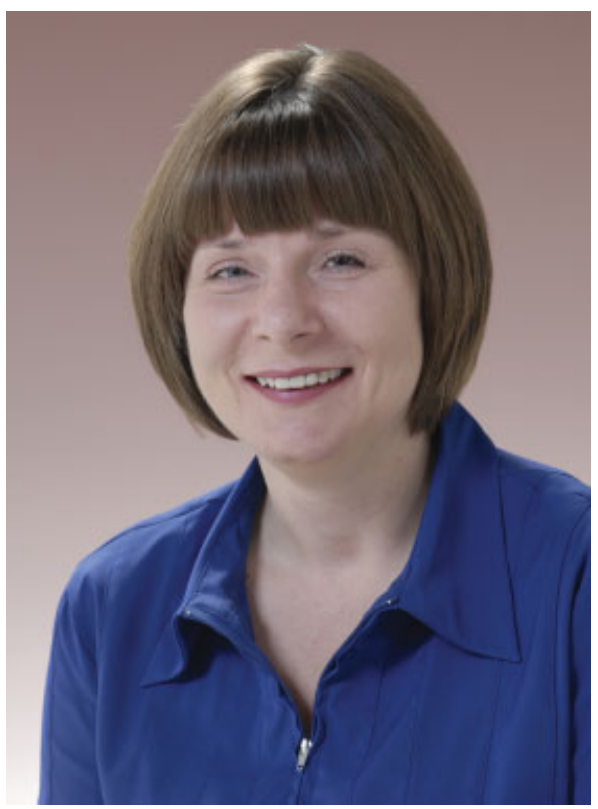

Fig. 2 Dr. Shannon Bates. therefore really pleased that this article has generated such huge interest around this very actual public health issue."

From Dr. Philippe de Moerloose (-Fig. 4), "I am very honored to receive one of the 2016 Most Popular Article Awards for a review on Congenital Fibrinogen Disorders,

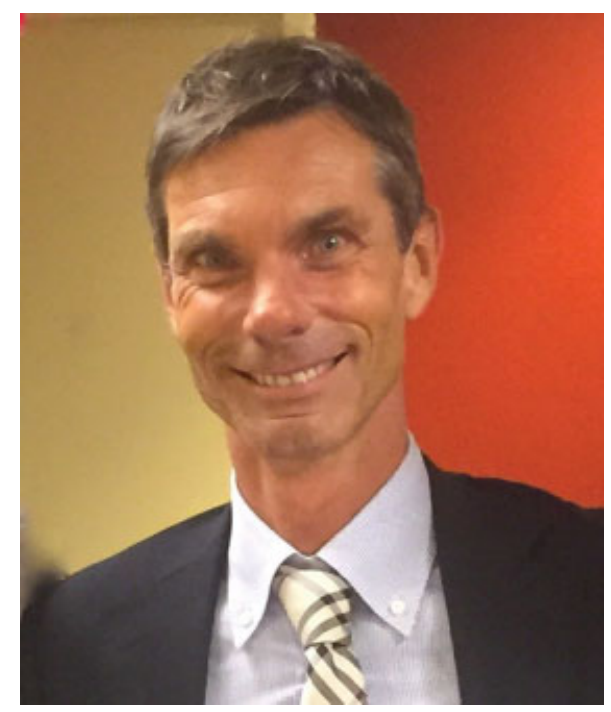

Fig. 3 Dr. Giuseppe Lippi. 


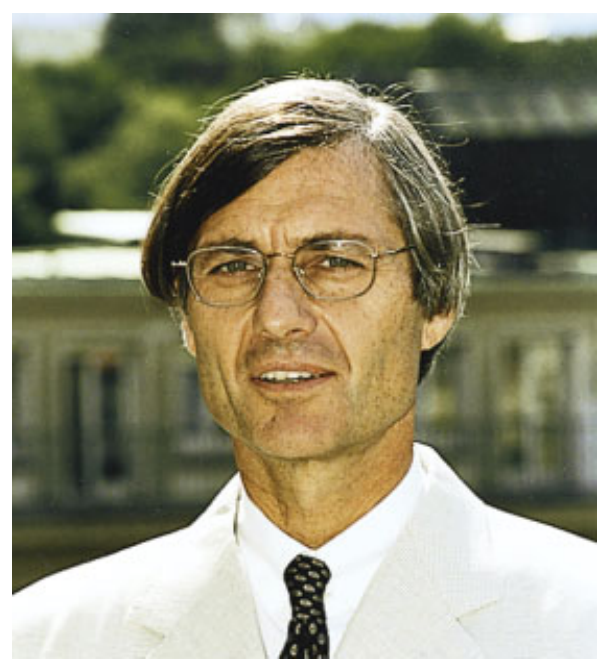

Fig. 4 Dr. Philippe de Moerloose.

written with my co-authors and close colleagues Alessandro Casini and Marguerite Neerman-Arbez. In Geneva, we have been working for more than 15 years on the genetic basis and clinical consequences of fibrinogen deficiencies. The fundamental knowledge gained in this field during the past decade has been quite substantial and has translated into a better comprehension of our patient phenotypes with a more tailored approach to their treatment. We are very pleased to learn that a large number of STH readers appreciated our updated review."

From Dr. Sanjeev Sethi (-Fig. 5), "It is indeed an honor to be selected for one of the 2016 Most Popular Article Awards. Understanding the pathology behind C3 glomerulopathy and atypical hemolytic uremic syndrome is the key to the correct diagnosis, evaluation, and management of these patients. Over the last few years great advances have been made in understanding the role of alternative pathway of complement in C3 glomerulopathy and atypical hemolytic uremic syndrome. With better elucidation of the pathophysiology, the

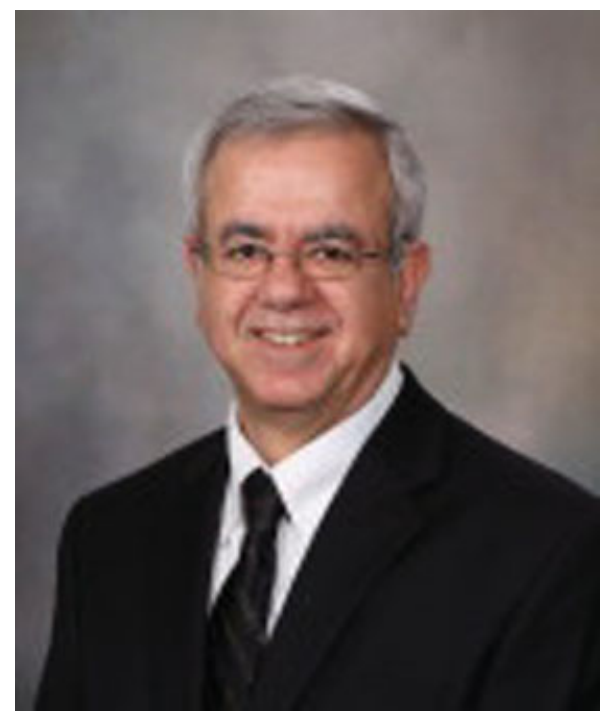

Fig. 5 Dr. Sanjeev Sethi. next step is the development of new agents that can target the specific underlying abnormality or defect that cause C3 glomerulopathy and atypical hemolytic uremic syndrome. I am very glad that our review of the pathology of these disease entities was well received, and I would also like to sincerely thank my colleague, friend and coauthor, Dr. Fernando Fervenza, with whom I have had numerous great discussions and collaborations."

I would like, as always, to thank not only all of the authors listed in the tables, but also the contributing authors who did not manage to make these listings, as well as all the guest editors of issues recently published in Seminars in Thrombosis $\mathcal{E}$ Hemostasis. Finally, as always, I look forward to seeing future listings!

\section{References}

1 Favaloro EJ. Editorial. Welcome to a Special Issue of Seminars in Thrombosis and Hemostasis-The Closing Issue for 2008. Semin Thromb Hemost 2008;34:693-696

2 Favaloro EJ. A tribute to Eberhard F. Mammen, M.D. (1930-2008). Semin Thromb Hemost 2008;34(8):703-707

3 Favaloro EJ. Editorial. Welcome to the first issue of Seminars in Thrombosis and Hemostasis for 2009. Semin Thromb Hemost 2009;35:1-2

4 Favaloro EJ. Editorial. Winners of the Inaugural Eberhard F. Mammen Award for Most Popular Article. Semin Thromb Hemost 2009; 35:587-590

5 Favaloro EJ. Editorial. 2009 Eberhard F. Mammen Young Investigator Award Winners. Semin Thromb Hemost 2010; 36:469-470

6 Favaloro EJ. Winners of the 2010 Eberhard F. Mammen award for most popular article during 2008-2009. Semin Thromb Hemost 2010;36(7):685-692

7 Favaloro EJ. 2011 Eberhard F. Mammen award announcements. Semin Thromb Hemost 2011;37(5):431-439

8 Favaloro EJ. 2012 Eberhard F. Mammen award announcements. Semin Thromb Hemost 2012;38:425-432

9 Favaloro EJ. 2013 Eberhard F. Mammen award announcements. Semin Thromb Hemost 2013;39:567-574

10 Favaloro EJ. 2014 Eberhard F. Mammen award announcements: Part I - most popular articles. Semin Thromb Hemost 2014;40(4): 407-412

11 Favaloro EJ. 2014 Eberhard F. Mammen award announcements: part II-Young Investigator Awards. Semin Thromb Hemost 2014; 40(7):718-723

12 Favaloro EJ. 2015 Eberhard F. Mammen Award Announcements: Part I-Most Popular Articles. Semin Thromb Hemost 2015;41(7): 673-679

13 Favaloro EJ. 2015 Eberhard F. Mammen Award announcements: part II-Young Investigator Awards. Semin Thromb Hemost 2015; 41(8):809-815

14 Bates SM. D-dimer assays in diagnosis and management of thrombotic and bleeding disorders. Semin Thromb Hemost 2012;38(7): 673-682

15 Lippi G, Favaloro EJ, Meschi T, Mattiuzzi C, Borghi L, Cervellin G. Ecigarettes and cardiovascular risk: beyond science and mysticism. Semin Thromb Hemost 2014;40(1):60-65

16 Moore GW. Recent guidelines and recommendations for laboratory detection of lupus anticoagulants. Semin Thromb Hemost 2014;40(2):163-171

17 Cuker A. Clinical and laboratory diagnosis of heparin-induced thrombocytopenia: an integrated approach. Semin Thromb Hemost 2014;40(1):106-114 
18 Demers M, Wagner DD. NETosis: a new factor in tumor progression and cancer-associated thrombosis. Semin Thromb Hemost 2014;40(3):277-283

19 Raskob GE, Angchaisuksiri P, Blanco AN, et al; ISTH Steering Committee for World Thrombosis Day. Thrombosis: a major contributor to global disease burden. Semin Thromb Hemost 2014;40(7):724-735

20 Favaloro EJ. Clinical utility of the PFA-100. Semin Thromb Hemost 2008;34(8):709-733

21 Warkentin TE. Heparin-induced thrombocytopenia in critically ill patients. Semin Thromb Hemost 2015;41(1):49-60

22 Zolfaghari S, Harenberg J, Froelich L, Wehling M, Weiss C. Development of a tool to identify patients' preference for vitamin $\mathrm{K}$ antagonist or direct oral anticoagulant therapy. Semin Thromb Hemost 2014;40(1):121-128

23 Althaus K, Greinacher A. MYH9-related platelet disorders. Semin Thromb Hemost 2009;35(2):189-203

24 Nurden AT. Platelet membrane glycoproteins: a historical review. Semin Thromb Hemost 2014;40(5):577-584

25 Harenberg J, Kraemer S, Du S, et al. Determination of direct oral anticoagulants from human serum samples. Semin Thromb Hemost 2014;40(1):129-134

26 Favaloro EJ, Lippi G. Laboratory testing in the era of direct or nonvitamin $\mathrm{K}$ antagonist oral anticoagulants: a practical guide to measuring their activity and avoiding diagnostic errors. Semin Thromb Hemost 2015;41(2):208-227

27 Wada H, Usui M, Sakuragawa N. Hemostatic abnormalities and liver diseases. Semin Thromb Hemost 2008;34(8):772-778

28 Harenberg J, Du S, Krämer S, Weiss C, Krämer R, Wehling M. Patients' serum and urine as easily accessible samples for the measurement of non-vitamin $\mathrm{K}$ antagonist oral anticoagulants. Semin Thromb Hemost 2015;41(2):228-236

29 de Moerloose P, Casini A, Neerman-Arbez M. Congenital fibrinogen disorders: an update. Semin Thromb Hemost 2013;39(6): 585-595

30 Sethi S, Fervenza FC. Pathology of renal diseases associated with dysfunction of the alternative pathway of complement: C3 glomerulopathy and atypical hemolytic uremic syndrome (aHUS). Semin Thromb Hemost 2014;40(4):416-421
31 Riedl M, Fakhouri F, Le Quintrec M, et al. Spectrum of complementmediated thrombotic microangiopathies: pathogenetic insights identifying novel treatment approaches. Semin Thromb Hemost 2014;40(4):444-464

32 Duga S, Salomon O. Congenital factor XI deficiency: an update. Semin Thromb Hemost 2013;39(6):621-631

33 Vivarelli M, Emma F. Treatment of C3 glomerulopathy with complement blockers. Semin Thromb Hemost 2014;40(4): 472-477

34 Baskurt OK, Meiselman HJ. Blood rheology and hemodynamics. Semin Thromb Hemost 2003;29(5):435-450

35 Senoo K, Lip GY. Comparative efficacy and safety of the nonvitamin $\mathrm{K}$ antagonist oral anticoagulants for patients with nonvalvular atrial fibrillation. Semin Thromb Hemost 2015;41(2): 146-153

36 Rodríguez de Córdoba S, Hidalgo MS, Pinto S, Tortajada A. Genetics of atypical hemolytic uremic syndrome (aHUS). Semin Thromb Hemost 2014;40(4):422-430

37 Boonyawat K, Crowther MA. Venous thromboembolism prophylaxis in critically ill patients. Semin Thromb Hemost 2015;41(1): 68-74

38 Xiao X, Pickering MC, Smith RJ. C3 glomerulopathy: the genetic and clinical findings in dense deposit disease and C3 glomerulonephritis. Semin Thromb Hemost 2014;40(4):465-471

39 Levi M, Poll Tv. Coagulation in patients with severe sepsis. Semin Thromb Hemost 2015;41(1):9-15

40 Franchini M, Coppola A, Tagliaferri A, Lippi G. FEIBA versus NovoSeven in hemophilia patients with inhibitors. Semin Thromb Hemost 2013;39(7):772-778

41 Lippi G, Favaloro EJ, Mattiuzzi C. Combined administration of antibiotics and direct oral anticoagulants: a renewed indication for laboratory monitoring? Semin Thromb Hemost 2014;40(7): 756-765

42 Knöbl P. Inherited and acquired thrombotic thrombocytopenic purpura (TTP) in adults. Semin Thromb Hemost 2014;40(4): 493-502

43 Levi M, Schultz M, van der Poll T. Sepsis and thrombosis. Semin Thromb Hemost 2013;39(5):559-566 